\title{
Executive Compensation And Ownership Structure
}

Rim Ben Hassen, Higher Institute of Management of Tunis, Tunsia

Jihene El Ouakdi, Higher School of Digital Economy of Manouba, Tunisia

Abdelwahed Omri, GEF2A Lab, Higher Institute of Management of Tunis, Tunisia

\begin{abstract}
The objective of this paper is to highlight the impact of ownership discrepancy and type (managers, families, institutions) on executive compensation. Based on a sample of French listed firms and using panel data regressions, the results show that capital concentration (Jensen 1986) negatively affects both the level of total executive compensation and the probability of use of stock option incentive plans. This confirms our theoretical alignment hypothesis. Moreover, the results show no evidence of the existence of a significant effect of ownership discrepancy on managerial compensation. Institutional shareholders are likely to encourage the use of stock option incentive plans and managerial ownership positively and significantly influences the level of total and fixed compensation. Family shareholding negatively affects executive compensation variables.
\end{abstract}

Keywords: Executive Compensation; Ownership Concentration; Discrepancy; Typology Of Shareholders

\section{INTRODUCTION}

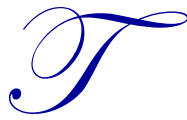

he issue of executive compensation has been the subject of much debate by several regulators. The special attention paid to the incentive mechanisms of managers has also stimulated the interest of several researchers to examine the link between business performance and the amount of compensation granted to executives.

The study of executive compensation is generally seen in the context of the agency relationship. The basic paradigm of the latter comes from the separation of management and ownership in companies with diffuse ownership. This leads to a possible divergence of interests between shareholders and managers. The latter take advantage of their strategic position at the head of the firm and the associated managerial discretion to pursue their own goals rather than those of shareholders. To address this problem and reduce agency costs related thereto, the agency theory proposes the establishment of incentive mechanisms for effective managers. These mechanisms include, primarily, writing compensation contracts between owners and managers based on performance indicators of the company (Core and Larcker (2002)).

While executive compensation is deemed to align the interests of executives with those of shareholders, it may lead, however, to significant deviations. Indeed, the financial scandals of recent years, paired with the growth of compensation plans, reveal that managers enjoy significant financial benefits even when their firm's performance is poor. Managerial compensation has seen significant examination in the context of the recent financial crisis, particularly due to the granting of executive bonuses at companies whose performance had deteriorated sharply. This type of controversy evokes the question of the role of governance mechanisms to control levels of managerial compensation that are sometimes deemed excessive (Barkema and Gomez-Mejia (1998)). Among these mechanisms, we examine the shareholding structure while controlling for certain characteristics of the board.

This study aims to examine the effect of the shareholding structure on managerial compensation in France while controlling for the impact of certain characteristics of the board, size, performance and debt. This research aims to extend a very sparse literature on the subject. In practical terms, the response to this problem allows us to 
identify the determinants of managerial compensation policy factors. Moreover, considering agency theory, we anticipate significant effects of the ownership structure and characteristics of the board structure on the managerial compensation system. This implies implicitly the existence of a potential substitution effect (negative effect on earnings) and/or complementarity (positive effect on earnings) between the compensation system, on the one hand, and shareholding structure and characteristics of the board of directors, on the other hand.

Thus we refer to two theories, namely the theory of optimal contracts (Core and Larcker 2002) and the theory of managerial power (Bebchuk and Fried 2003). The first states that managerial compensation is considered to be a governance mechanism that can resolve potential agency conflicts between the shareholders and the manager. The second theory, for its part, holds that managerial compensation does not constitute a solution to the agency problem but may be the cause. Indeed, the manager could influence the decisions made by the board, including those related to compensation. Thus, two assumptions relating to the theories presented above are to be tested.

The first, called alignment, states that capital concentration entails effective control of the policy of managerial compensation. Similarly, given its risk aversion, the manager could accept a low level of compensation in exchange for higher job security (Gomez-Mejia et al., 2003, Ben Amoako-Adu, 2011). The second hypothesis states that the majority shareholder is able to try to expropriate the wealth of minority shareholders through compensation (Bertrand and Schoar 2006; Croci et al., 2012).

To identify critical variables of managerial compensation systems, we examine a sample of French companies belonging to the SBF 120 index. Our study period lasts four (4) years from 2007 to 2010 . Note that the French context is interesting to analyze for various reasons. The first concerns the considerable evolution of governance mechanisms in recent years in France, including the Viénot reports 1995, 1999 and Button 2002. In addition, companies have multiplied the creation of specialized committees and, in particular, compensation committees. In this regard, we think that it is interesting to consider the impact of these new measures of governance on levels of executive compensation.

The second reason comes from the fact that our knowledge of the political executive compensation system has been little studied in the French context. This can be explained by the fact that, until recently, information on this issue has not been available. Indeed, transparency on compensation has gradually developed over recent years (Wirtz (2009)). In this regard, the Viénot report (1999) encouraged the publication of details of managerial compensation in the case of listed French companies and stock option plans in the new economic regulations (NRE) of 15 May 2001. This establishes that the corporate proxy statement must account for the full pay, the granting of option purchase actions and benefits paid to each executive manager. The Breton Act of 26 July 2005 has enhanced transparency by requiring the inclusion in the annual report of a description of the fixed, variable and exceptional components of compensation, and the criteria under which they have been evaluated and the circumstances in virtue of which they were established.

A third reason for the choice of the French context arises from its shareholding structure. Indeed, various studies agree on the highly concentrated nature of ownership in France and the frequent use of mechanisms that separate voting rights and shareholding rights. These studies also highlight the presence of three major shareholders: managers, families and institutions.

The features of managerial compensation and ownership structure are behind the choice of our research question that propose to highlight the impact of the concentration of ownership, the separation between ownership and control, and the type of shareholder (managers, families, institutions) on executive compensation in French companies listed on the SBF 120 index. Simultaneously, we control the impact of certain variables of the board, performance, size and debt. The answer to this research question will, in the design of managerial compensation contracts, monitor the effect of certain key variables.

To empirically test the hypothesis of our study, we adopt a regression-based approach. Our dependent variables are none other than the level of total fixed compensation and variable compensation (bonus) of the manager. We set the dependent variable equal to one (1) in a binary variable if the firm distributes stock options to 
its managers. Our explanatory variables are mainly the shareholding structure. We also regress some variables representing the board. We control, too, for the effects of size, leverage and profitability.

This article is organized as follows. The first section presents a literature review on the effect of ownership structure on executive compensation that permits us to develop the hypotheses of this study. Research methodology, sample and variable measurement are detailed in s a second section. We analyze the results of our empirical investigation in a third section. The last section concludes the paper.

\section{THEORETICAL DEVELOPMENT}

The study of the relationship between nature and executive compensation constitutes a privileged and recent topic in the economic literature. Many studies have been carried out in order to test the hypothesis that ownership structure affects executive compensation. These studies support or oppose the conclusion reached by Jensen and Meckling (1976). This confirms the theory of optimal contracts (Core and Larcker 2002). In contrast, the so-called managerial power (Bebchuk and Fried 2003) theory holds that managerial compensation is not a solution to the agency problem but may be the cause. Indeed, the manager could influence the decisions made by the board of directors, including those related to compensation.

\subsection{Concentration Of Ownership And Executive Compensation}

Under the framework of the agency theory, the controlling shareholders are likely to play a particularly active role in the control of directors and in limiting the agency relationship between shareholders and managers (Jensen and Meckling (1976)) conflicts. In companies whose capital is diffuse, managers have considerable leeway to guide the decisions of the board and to get what they ask for in reporting earnings. Thus, in this type of business, the lack of control by a blockholder tends to increase the cost of incentive compensation. Moreover, when the capital is held by a small number of shareholders, the need for a significant level of compensation or the establishment of a political incentive is not feasible given risky management practices which are limited or even nonexistent. Indeed, blockholders are encouraged to invest in management control to ensure that they take ownership of a significant share of the additional profits (Shleifer and Vishny (1986)). This call to action is to guarantee their effectiveness. It is also the least expensive in terms of agency cost caused by managerial discretion (Mtanios and Pequerot (1999)) costs. Since then, concentrated ownership has been one of the control mechanisms of managers (Shleifer and Vishny (1986)).

A large part of the financial literature is concerned with the pressure that can be applied by blockholders on managers to get them to the goal of maximizing the value of the firm. Shleifer and Vishny (1986) suggest that the presence of controlling shareholders exercising closer supervision over the opportunistic behavior of managers helps in ensuring the reduction of their discretionary areas. Thus, the concentration of ownership appears as a guarantee of security for minority shareholders against the opportunism of manager.

It follows that based on these arguments, ownership concentration negatively affects total executive compensation. The results of empirical studies on the concentration of ownership revealed, overall, a negative influence of the presence of controlling shareholders on executive compensation (Haid and Yurtoglu (2006) on the German market and Mehran (1995) on the U.S. market). These authors reflect this association to a substitution effect between the blockholders' control and the payment of higher salaries to their executives. In this respect, and like other European countries, corporate governance in France is characterized by shareholder concentration (La Porta et al. (1999)) (Faccio and Lang (2002)). Thus, we expect that blockholders actively act for the control of managers, particularly in their compensation. Accordingly, we issue our first hypothesis:

Hypothesis 1: The percentage of capital held by the main non-executive shareholder negatively affects the level of executive compensation.

\subsection{Separation Of Ownership/Voting And Executive Compensation}

Unlike the Anglo-Saxon context, the majority of firms in the countries of continental Europe and Asia use mechanisms counteracting the "principle of one share-one vote". This dissociation between ownership and control is 
effected through the issue of shares to multiple voting classes, the organization of firms in pyramid structures and cross-holdings (Bebchuk (1999), La Porta et al. (1999), Faccio and Lang (2002)). As shown in Faccio and Lang (2002), examining a sample of 3,592 European firms, there is a divergence between the right to the capital and voting rights of the controlling shareholder holding more than $10 \%$ of the vote. These authors found that the blockholder has $34.60 \%$ of capital and $37.75 \%$ of capital vote. As an indication, the majority shareholder in Italy has averaged $38.33 \%$ against $48.26 \%$ of capital vote. In France the majority shareholder holds on average $46.68 \%$ against $48.32 \%$ of capital vote.

The phenomenon of dissociation gives the holder of shares of multiple voting classes the ability to maintain an almost exclusive control of the company while holding very small part of capital. This situation benefits the expropriation of minority shareholders through the phenomenon of private benefits. Indeed, Boubaker and Labegorre (2006) show that excess control provides the majority shareholder the ability and incentive to make decisions that promote their interests and sometimes at the expense of maximizing shareholder value. It can, for example, not select the most profitable investment projects for all shareholders. In this regard, Johnson et al. (1996) note that the control exercised by blockholders is not necessarily a source of efficiency for the company, which might strengthen the majority-minority conflicts.

The different impacts of the dissociation between ownership and control are less studied empirically, mainly because under U.S. law, this is nearly nonexistent in the United States. Recently, taking a sample of 150 U.S. firms during 1995-2003, Masulis et al. (2009) observe a positive association between executive compensation and excess control that is captured through two measures: the ratio of divergence (vote/capital) and "wedge" (votecapital).

From a survey of 160 German firms, Haid and Yurtoglu (2006) found that excess control affects the relationship between executive compensation and firm size. Indeed, it appears that the «wedge» positively influences the high managerial compensation observed in large firms. However, no direct effect of this excess of control over executive compensation has been revealed. Excess control may pose a threat of expropriation of minority shareholders. We thus issue our second hypothesis:

Hypothesis 2: a separation between ownership and control positively affects total executive compensation.

\subsection{Family Shareholders And Executive Compensation}

Family ties may have an impact on executive compensation ( Ben Amoako-Adu et al. (2011), Croci et al. (2012)). There are several reasons for this. Indeed, empirical evidence (Gomez-Mejia et al. (2001); Ben AmoakoAdu et al. (2011); Croci et al. (2012)) suggests that managers who have family ties with the owner have high job security.

In opposition to Beehr et al. (1997), a close head of the family has naturally two interrelated roles: a worker role (as a steward for the company) and the role of a non-worker (as the supervisor of the obligations of the family). As a reaction to this duality of roles, the manager belonging to a family business is rewarded with relatively secure employment (Gomez-Mejia et al. (2001); Croci et al. (2012)). Moreover, the literature on performance evaluation suggests that evaluators are more likely to attribute positive performance to employees because of bonding between supervisors and those who are judged. Thus, in companies controlled by families, board members (in their role as controller) may have less incentive to remunerate managers. Indeed, poor performance can then be interpreted as bad luck rather than the result of the incompetence of these managers. Applying the logic of agency theory, the above scenario suggests that within family-controlled businesses managers could exchange very high job security for low income if they have links with families.

In this type of firm, the divergence of interests between principal (the family) and agent (the manager) is mitigated by the fact that there is an almost total confusion of property and control functions. This situation has led many theorists such as Fama and Jensen (1983) to suggest that, unlike firms with dispersed ownership, agency problems arising from conflicts of interest between managers and shareholders do not have a place or are insignificant in family businesses. This direct involvement of family members in the management of the firm affects 
executive compensation, as they reduce their excessive withdrawals. This inverse relationship can be observed in the light of the hypothesis of expropriation of private benefits. Indeed, the huge family involvement in the control and management of the firm is likely to provide freedom of discretionary action for managers to meet their own objectives to the detriment of the interests of other shareholders. The severity of this problem tends to increase in the presence of separation between ownership and control, particularly in the case of pyramidal structures.

Moreover, based on a sample of Japanese firms during, Basu et al. (2007) concluded that family control tends to use its position to overpay these members as executives. These authors state that excessive compensation is a sign of lax governance. Similarly, other empirical studies in Italy by Barontini and Bozzi (2011) and in Germany by Haid and Yurtoglu (2006) validate this positive association. The ownership structure of firms in France is characterized by the presence of family groups as controlling (Faccio and Lang (2002)). Thus, we can propose our third hypothesis:

Hypothesis 3: Family ownership positively affects total executive compensation.

\subsection{Shareholding Managers And Executive Compensation}

As part of the alignment hypothesis, the greater the share capital held by the manager, the higher his interests may be aligned with those of other shareholders, thereby limiting the risk of opportunistic managerial behavior (Jensen and Meckling (1976)). Consequently, a greater involvement of the executive in capital holding should limit the risk of an excessive compensation policy, to the detriment of shareholders.

In the Anglo-Saxon context, Lambert et al. (1993) and Core et al. (1999) verify that the level of executive compensation is lower when the executives' participation in capital holding is larger. One can also assume that the manager more readily accepts a greater share of flexible pay linked to company performance. Shareholding management has both positive and negative characteristics. When managers hold a small percentage of securities, the increase of that percentage can better align their interests with those of outside shareholders. Otherwise, the managers eventually pursue only their own interests, regardless of outside shareholders. However, it should be noted that the inverse relationship could be observed under the guise of a rooting hypothesis manager. Indeed, the theory of the existence of rooting suggests an active behavior to take advantage of loopholes or neutralize controls. This behavior allows a transfer of wealth from shareholders in favor of managers, particularly in the form of wages (Shleifer and Vishny (1989)).

In other words, holding a large share of capital would allow the manager to compel the directors to accept a compensation policy favoring their self-interest. Roussel and Trepo (1999) observe that in France and in companies where managers act on their compensation, bonuses are less tied to the performance of the company. Barak et al. (2011) confirm this positive association stating that excessive compensation has the effect of deterioration in the value of the firm.

Hypothesis 4: The percentage of capital held by the manager positively affects their level of compensation.

\subsection{Ownership Of Institutional Investors And Executive Compensation}

According to the agency theory, institutional shareholder may serve as a mechanism for effective governance. Indeed, the augmentation of participation in corporate capital adds binding dimensions for managers in their opportunistic behavior. Mtanios and Paquerot (1999) argue that institutional investors exercise strict control over the management of the firm in which they invest through two levers: (1) They have privileged access to information because of their activities and many investments they make enable them to analyze in detail the accounts of the company, its growth prospects and quality of its management and (2) They have seats on the board and can therefore influence the decisions of managers in order to maximize the return on their investment.

Ginglinger and L'Her (2006) state that the institutional shareholder is also a guarantee of protection of minority shareholders's interests, when the ownership structure is dominated by a majority shareholder. Thus, they 
will try to stop any behavior detrimental to their interest, in particular the phenomenon of private benefits. It follows that based on these arguments institutional ownership is inversely related to the total compensation of managers.

Khan et al. (2005) study the impact of concentration and dispersion of institutional properties on the level of executive compensation. They point out that institutional concentration leads to a lower level of compensation. However, when dispersed, the level increases. According to these authors, institutional investors holding small units are not encouraged to collect internal company information to monitor managerial behavior because of its high cost. In this case, managers are free from control and exercise their discretion in order to assign a higher pay. Ozkan (2007) shows that the level of executive compensation is significantly and negatively related to institutional ownership concentration. This result is consistent with the theoretical literature on the role of principal shareholders. In other words, there is a substitution relationship between the influence of institutional investors to monitor management and compensation thereof.

Hypothesis 5: Concentration of institutional ownership negatively affects executive compensation.

\section{METHODOLOGY}

Recall that we propose to study the impact of ownership on executive compensation structure in France, while controlling for the effect of certain variables of the Board, size, profitability and debt.

\subsection{Data And Sample}

This research is conducted on a sample of companies listed on the SBF 120 index. Of all the SBF 120 companies listed during the period 2007-2010, we removed (1) companies that do not publish the individual and personal compensation of the CEO, (2) companies limited by shares because the managers are paid statutory profits, and (3) outliers identified by the level of compensation in addition to the stock options received by the executive in relation to the compensation of other executives of listed companies in the same index. Individuals whose compensation is very low or very high compared to the average are thus removed. To perform the analysis, information on executive compensation should be available over the four years of study. Our final sample consisted of 97 companies. The number of observations is thus about 388 company-year observations.

For the purposes of this research, most of the information on the compensation of directors and managers was collected manually from annual reports (documents), published on the websites of the SBF 120 companies. Data on governance variables were also collected from the annual reports of the companies concerned. Finally, financial and market data were extracted from the Worldscope data base.

\subsection{Executive Compensation Measure}

The terms of executive compensation are complex and pose empirical problems. The aggregate compensation of an manager is in fact the sum of four components, namely, (1) a fixed compensation, (2) an annual bonus, (3) options to purchase shares and /or bonus shares, and finally, (4) a set of various elements: fringe benefits, fees, insurance underwriting and severance pay.

Fixed compensation: The dependent variable ( LnRemFix $_{\text {it }}$ ) is the natural logarithm of the fixed compensation in thousands of euros allocated to manager i. The fixed and variable compensation is measured as follows: Ln (fixed compensation $_{\text {it }}$ (Croci et al. (2012).).

The annual bonus: The variable (Bonus ${ }_{i t}$ ) is the logarithm of the annual variable compensation (the short-term incentive) of the manager assigned to $i$ paid in year $t+1 \mathrm{t}$. The variable annual bonus is measured as follows: $\mathrm{Ln}$ (Annual Bonus it $)$ (Croci et al. (2012).).

Total compensation: The global variable compensation ( $\left.\operatorname{LnRemTot}_{\text {it }}\right)$ is the logarithm of the sum of the fixed salary and annual bonus (Croci et al. (2012).). 
Stock Options: The representative of this variable (AttSo) is measured through a dummy variable equal to 1 if the firm assigns stock options to its directors and 0 otherwise.

\subsection{Independent Variables}

The concentration of ownership : To measure the concentration of ownership, we use two types of measures. The first (Herfindahl) concerns the Herfindahl-Hirschman indicator proposed by Demsetz and Lehn (1965). The second (Conc), in turn, determines the share held by the largest shareholder in the capital structure.

Discrepancy: The separation between ownership and control is measured by a variable (discrepancy) which is equal to the difference between the voting rights percentage of the top controlling shareholder and the rights to cash flow as a percentage of the top controlling shareholder.

Manager ownership: This variable (KalDirig) is defined as the percentage of shares held by the CEO in the case of the combination of the functions of board chairman and chief executive manager or the percentage of shares held by the CEO in the event that these functions are separated.

Family ownership: Family ownership is often associated with a wide involvement of the founders and other family members in positions of leadership within the company. The family shareholder (KalFlle) is measured by the percentage of shares held by family members.

Institutional ownership: This variable (Invins) is defined as the percentage of shares held by French and foreign institutional investors.

\subsection{Control Variables}

The ownership structure is not the only determinant of executive compensation. The empirical literature highlights other factors that may influence the level of executive compensation. We then control for the effect of firm size (Smith and Watts (1992) and Core and Guay (1999)), performance (Benito and Conyon (1999)), debt (Jensen 1986), The percentage of independent directors on the board (Core et al. (1999)), Cordeiro and Veliyath (2003) and Conyon et al. (1995).

\section{METHODOLOGY}

To better understand the effect of ownership structure on executive compensation in fixed and variable form, while controlling for the effect of certain variables characterizing the Board, size, performance and debt, we adopt a multiple regression model using panel data.

Our Probit model regress the binary variable representing granting of stock option (AttSo). Indeed, the dependent variable in this case is a dichotomous variable taking the value 1 if the firm assigns stock options to its directors and 0 otherwise. Our regression models of the value of total compensation (LnRemTot), fixed compensation (LnRemFix) and bonus (Bonus Ln) are based on panel data. So, it is often useful to identify the effect associated with each individual that is common or specific. This effect can be fixed or random. Since we study the three forms of compensation (fixed, variable and total) and the possibility of awarding incentive plans based on options to purchase shares, we end with the analysis of 8 model regressions. 
Table 1. The Model

\begin{tabular}{ccl}
\hline Equation & Model & \multicolumn{1}{c}{ Regression } \\
\hline \multirow{2}{*}{ Equation1 } & $\mathbf{1}$ & LnRemTot $=\mathrm{f}$ (Conc, Invins, KalDirig, IndCA, Duality, LnActif, ROE, Endt) \\
& $\mathbf{2}$ & LnRemFix = f (Conc, Invins, KalDirig, IndCA, Duality, LnActif, ROE, Endt) \\
& $\mathbf{3}$ & Bonus = f (Conc, Invins, KalDirig, IndCA, Duality LnActif, ROE, Endt) \\
& $\mathbf{4}$ & Attso = f(Conc, Invins, KalDirig, IndCA, Duality, LnActif, ROE, Endt) \\
\hline \multirow{2}{*}{ Equation 2 } & $\mathbf{1}$ & LnRemTot = f (Discrepancy, KalFlle, Herfindahl, Duality, IndCA, LnActif, ROE, Endt) \\
& $\mathbf{2}$ & LnRemFix = f (Discrepancy, KalFlle, Herfindahl, Duality, IndCA, LnActif, ROE, Endt) \\
& $\mathbf{3}$ & Bonus = f (Discrepancy, KalFlle, Herfindahl Duality, IndCA, LnActif, ROE, Endt) \\
\hline
\end{tabular}

\section{ANALYSES AND DISCUSSION OF RESULTS}

\subsection{Descriptive Analysis}

Table 2 presents descriptive statistics for the dependent variables, and independent control of our study. On average, a French manager receives a total compensation of 1,549,432 EUR. This compensation also comprises a fixed part on average of 632 to 764 EUR and an average variable component on the order of 745497 EUR. The dispersion of the wage compensation is very pronounced.

In terms of ownership structure, the largest shareholder holds on average $34.37 \%$ of the capital. This result confirms the thesis that the shareholding structure of French firms is relatively concentrated (Faccio and Lang (2002)).The Herfindahl concentration index confirms this result (the average is around 26.47\%). These figures may reveal the existence of a potential conflict between majority and minority shareholders. This is all the more important since the French legal environment is not ready to protect minority shareholders because of its weak rules of legal protection and the ineffective law enforcement system (La Porta et al. (1998)). The gap in ownership/voting is an average of about $2.43 \%$. In some cases, this gap reaches $21 \%$. This is explained by the fact that in France, a large majority of companies use double voting rights. These rights, non-negotiable, are removed in case of transfer of the shares. This practice helps to strengthen control by majority shareholders by increasing the separation between cash flow rights and voting rights.

Claessens et al. (2002) show that the difference between rights to cash flow and voting rights is accentuated for family firms in Asia. This result seems to be confirmed by Ginglinger and L'Her (2006) on a large sample of French firms conducting repurchases. These findings may explain the fact that the percentage of shares held by the family is on average equal to $9.62 \%$ in our sample. Table 3 also shows that, in the French context, on average $6.52 \%$ of the capital held by the managers. It should be noted also that the proportion of shares held by institutional investors is on average about $35.62 \%$. It turns out that this type of powered ownership is, indeed, widespread in France. The increase in assets held by these investors leads them to become full participants in the systems of corporate governance. 
Table 2. Descriptive Statistics

\begin{tabular}{|c|c|c|c|c|}
\hline Continuous Variables & Minimum & Maximum & Standard Deviation & Average \\
\hline Concent & 0.0356 & 0.9993 & 0.2265 & 0.3437 \\
\hline Discrepancy & -0.1455 & 0.2128 & 0.0521 & 0.0243 \\
\hline Herfindhal & 0.0006 & 17.64 & 0.9607 & 0.2647 \\
\hline KalFlle & 0 & 0.8098 & 0.1675 & 0.0962 \\
\hline Invins & 0 & 0914 & 0.2637 & 0.3562 \\
\hline KalDirig & 0 & 0.7224 & 0.1330 & 0.0652 \\
\hline IndCA & 0.1111 & 0.7272 & 0.1704 & 0.4486 \\
\hline ROE & -283.29 & 1443.7 & 78.69 & 14.90 \\
\hline LnActif & 4.5454 & 13.1875 & 1.6073 & 8.7061 \\
\hline Endt & 0.0001 & 0.6284 & 0.5263 & 0.3367 \\
\hline RemTot (Euro) & 0 & 10393267 & 1075352 & 1549432 \\
\hline RemFix (Euro) & 0 & 2729179 & 417754 & 764632 \\
\hline Bonus (Euro) & 0 & 8717872 & 805327 & 745497 \\
\hline \multicolumn{2}{|c|}{ Binary Variables } & Frequency & Proportion & \\
\hline \multirow{2}{*}{ Duality } & 0 & 212 & 54.64 & \\
\hline & 1 & 176 & 45.36 & \\
\hline \multirow{2}{*}{ AttSo } & 0 & 54 & 13.92 & \\
\hline & 1 & 334 & 86.08 & \\
\hline
\end{tabular}

In addition, we conducted tests of mean difference for the purposes of a thorough study of the characteristics of our sample. These tests are shown in Panels A and B of Table 3. The first test is to divide the sample into two groups of companies. The first group includes companies with a value of total compensation above the average of the entire sample. The second group includes companies with a total value of compensation below the average. We subsequently changed our dependent variable (total compensation) into a dichotomous variable equal to 1 if the firm pays its executives with a value higher than its average value and 0 otherwise. Then, we analyzed the difference in averages for the different variables representing the shareholding structure of one subgroup to another. The average difference test used is a parametric test (student $t$ ).

Panel A of Table 3 shows that companies distributing high earnings (above the average) have a concentration (Conc) relatively lower than companies that pay lower than average. The mean differences are significant at the 5\% level between the two groups of companies. This result is confirmed by measuring the gap between ownership and control (Discrepancy).

Table 3 shows that firms with small gap between ownership and voting (Discrepancy) pay their executives large amount. Regarding the share of institutional investors, the results show that companies that pay high compensation to executives are those who have a strong presence of institutional investors. The differences were significant between the two groups at the $1 \%$ level. As for the variables representing the characteristics of the board, the mean difference tests show that firms with high earnings have more independent directors and opt less for a dual function CEO and chairman of the board than firms in the second group. Finally, large firms are those that distribute a higher salary compared to their smaller counterparts.

Panel B of Table 3, meanwhile, presents tests of mean difference between companies distributing stock options to their executives and those choosing not to use this type of managerial incentive indexed to performance. The results show that companies awarding stock options have a concentration (Conc), but rather low institutional ownership (Invins) compared to firms not awarding stock options. The mean differences are significant at the $1 \%$ level between the two groups of companies. Similarly, we note that the percentage of independent directors is higher in firms opting for stock option programs.

\subsection{Multivariate Analysis}

Tables 4 and 5 show the results of estimating regression models for total compensation (LnRemTot), fixed compensation (LnRemFix) and variable compensation (LnBonus) represented by the first three models of each of equations (1) and (2). 
The estimation results show no evidence of the existence of a significant effect of the proportion of shares held by the controlling shareholder (Conc) and the gap between ownership and voting (Discrepancy) on the three dependent variables of our research. However, we note a negative and significant effect of concentration of ownership, as measured by the Herfindahl index and total executive compensation. This allows us to accept our first hypothesis. This result is similar to that found in previous studies found in other contexts such as Elston and Goldberg (2003), Lambert et al. (1993) and Core et al. (1999) and Cyert et al. (2002 ) and Veliyath Cordeiro (2003), Ozkan (2007), and Haid and Yurtoglu (2006). Thus, it appears that in the French context, ownership is more concentrated and more controlled by majority shareholder. Indeed, the use of high compensation to align the interests of shareholders with those of managers is reduced.

Table 3. Tests Of Mean Difference: Average Total Compensation And Allocation Of Stock Options

\begin{tabular}{|c|c|c|c|c|c|c|}
\hline & \multicolumn{6}{|c|}{ Test Of Difference In Means } \\
\hline & \multicolumn{3}{|c|}{ Average Total Compensation } & \multicolumn{3}{|c|}{ Granting Of Stock Options } \\
\hline & $\begin{array}{c}\text { Average } \\
\text { Earnings }\end{array}$ & Average & T-Test & $\begin{array}{c}\text { Award Of } \\
\text { Stock Options }\end{array}$ & Average & T-Test \\
\hline \multirow{2}{*}{ Concent } & 1 & 0.3166 & \multirow{2}{*}{$2.1345 * *$} & 1 & 0.3297 & \multirow{2}{*}{$3.4978 * * *$} \\
\hline & 0 & 0.3658 & & 0 & 0.4407 & \\
\hline \multirow{2}{*}{ Discrepancy } & 1 & 0.0105 & \multirow{2}{*}{$4.3143 * * *$} & 1 & 0.0255 & \multirow{2}{*}{-0.6843} \\
\hline & 0 & 0.0351 & & 0 & 0.0203 & \\
\hline \multirow{2}{*}{ Herfindahl } & 1 & 0.3393 & \multirow{2}{*}{-1.1167} & 1 & 0.2632 & \multirow{2}{*}{0.1695} \\
\hline & 0 & 0.2105 & & 0 & 0.2739 & \\
\hline \multirow{2}{*}{ KalFlle } & 1 & 0.0811 & \multirow{2}{*}{1.6020} & 1 & 0.1003 & \multirow{2}{*}{-1.4598} \\
\hline & 0 & 0.1076 & & 0 & 0.0729 & \\
\hline \multirow{2}{*}{ KalDirig } & 1 & 0.0643 & \multirow{2}{*}{0044} & 1 & 0.0634 & \multirow{2}{*}{0.5682} \\
\hline & 0 & 0.0649 & & 0 & 0.0730 & \\
\hline \multirow{2}{*}{ Invins } & 1 & 0.4170 & \multirow{2}{*}{$-3.1832 * * *$} & 1 & 0.3832 & \multirow{2}{*}{$3078 * * *$} \\
\hline & 0 & 0.3300 & & 0 & 0.2764 & \\
\hline \multirow{2}{*}{ IndCA } & 1 & 0.4653 & \multirow{2}{*}{$-2.2504 * *$} & 1 & 0.4518 & \multirow{2}{*}{$3368 * * *$} \\
\hline & 0 & 0.4266 & & 0 & 0.3864 & \\
\hline \multirow{2}{*}{ Duality } & 1 & 0.3496 & \multirow{2}{*}{$3.6164 * * *$} & 1 & 0.4384 & \multirow{2}{*}{1.5937} \\
\hline & 0 & 0.5312 & & 0 & 0.5555 & \\
\hline \multirow{2}{*}{$\mathbf{O E}$} & 1 & 14.4734 & \multirow{2}{*}{0.1477} & 1 & 15.4282 & \multirow{2}{*}{-0.4304} \\
\hline & 0 & 15.5245 & & 0 & 12.9611 & \\
\hline \multirow{2}{*}{ LnActif } & 1 & 9.6004 & \multirow{2}{*}{$10720 * * *$} & 1 & 8.6227 & \multirow{2}{*}{$2.8139 * *$} \\
\hline & 0 & 8.0528 & & 0 & 9.2104 & \\
\hline Fndt & 1 & 0.3512 & 04118 & 1 & 0.3425 & -10100 \\
\hline Endt & 0 & 0.3270 & -0.4118 & 0 & 0.3045 & -1.0100 \\
\hline
\end{tabular}

Panel A of this table presents the average difference tests by dividing the sample according to the variable average total compensation $(=1$ if the total compensation paid by the company is above the average total compensation of the entire sample). Panel B of this table presents the average difference tests by dividing the sample according to the variable allocation of stock options (= 1 if the company awards stock options). ***, **, *: statistics are significant to the respective thresholds of $1 \%, 5 \%$ and $10 \%$.

The presence of a negative effect of the concentration of ownership on total compensation can be explained by the fact that the controlling shareholder is a guarantee of security of minority interests in a concentrated structure (Morck et al. (1988)). To this end, and as an additional control mechanism of leadership, ownership concentration replaces executive compensation. The direction of this relationship can reinforce the arguments of agency theory and the alignment argument that shareholders' interests are aligned with those of the managers by the award of high compensation. In this situation, a higher level of compensation or compensation policy based on incentives elements will be recommended to increase the effort of managers (Jensen and Meckling (1976)). Furthermore, the negative relationship between executive compensation and share ownership concentration detected in our empirical analysis can also be explained by the fact that the probability of removal of the manager is high in a business where the capital is held by a limited number of shareholders. Thus, to prevent their replacement by others, the managers of companies will be encouraged to align shareholder expectations by limiting, for example, its discretions in compensation (Kaplan (1994)). 
Regarding the type of shareholder, it appears that the share of managers (KalDirig) influences positively and significantly the level of total and fixed compensation. Indeed, the identity of shareholders may have major implications for executive compensation. This result confirms our fourth hypothesis. In other words, this result supports the hypothesis that assumes rooting managers benefit from their holding of a significant fraction of the capital to force administrators to tolerate the payment of a total fixed compensation (Barak et al. (2011)).

The proportion of institutional investors (Invins) has no significant impact on the three variables representing the level of managerial compensation. In addition, Table 5 shows that family ownership (KalFlle) negatively affects variable executive compensation. This result rejects the third hypothesis of this work as well as the assumption of expropriation of private benefits.

Indeed, it appears that family members are more involved in the management of the firm, thus affecting executive compensation by reducing their excessive withdrawals.

Tables 4 and 5 show a negative and significant effect of the proportion of independent directors (IndCA). This effect persists in all the equations of the two models. Indeed, it turns out that in the French context, the presence of independent directors on the board reduces the incentive to use high earnings (total, fixed and variable) to ensure alignment of interests of executives with those of shareholders. These two mechanisms of governance are now substitutes according to our results (Ben Amoako-Adu (2011)).

Also, we note a positive effect of the variable (Duality) on variable compensation (bonus). Indeed, combining the functions of CEO and chairman of the board tends to increase the variable and total share of executive compensation. In this case, the president and top director wields great power in the selection of directors and then in fixing their compensation. Thus, he can freely impose his compensation.

Table 4. Estimation Results Of The Regressions (Models 1 To 3 In The $1^{\text {st }}$ Equation)

This table presents the results of panel data regressions for our sample. ***, **, *: statistics are significant to the respective thresholds of $1 \%, 5 \%$ and $10 \%$.

\begin{tabular}{lcc|cc|cc}
\hline & \multicolumn{2}{c|}{ LnRemTot } & \multicolumn{2}{c}{ LnRemFix } & \multicolumn{2}{c}{ Bonus Ln } \\
\hline Constant & Coef. & $\mathbf{Z}$ & Coef. & $\mathbf{Z}$ & \multicolumn{2}{c}{ Coef. } \\
Concent & $14.0524 * * *$ & 45.31 & $13.4966 * * *$ & 57.89 & $14.3956 * * *$ & 22.17 \\
Inv Ins & 0.1373 & 0.71 & 0.0248 & 0.17 & 0.3376 & 0.74 \\
Kal Dirig & -0.0272 & -0.27 & 0.0531 & 0.70 & -0.0665 & -0.30 \\
IndCA & $0.6593 * *$ & 2.34 & $0.4499 * *$ & 2.12 & 0.7493 & 1.18 \\
Duality & $-0.4982 * *$ & -2.07 & $-0.4482 * *$ & -2.48 & $-1.6986 * *$ & -2.75 \\
LnActif & 0.0039 & -0.07 & 0.0645 & 1.49 & 0.2018 & 1.59 \\
ROE & 0.0137 & 0.39 & 0.0060 & 0.23 & -0.0687 & -0.69 \\
Endt & $-0.0006 * * *$ & -2.73 & $-0.0005 * * *$ & -3.06 & -0.0006 & -1.21 \\
F-test & 0.0077 & 0.16 & -0.0081 & -0.23 & -0.0107 & -0.11 \\
\hline
\end{tabular}


Table 5. Estimation Results Of The Regressions (Models 1 To 3 In The $2^{\text {nd }}$ Equation)

This table presents the results of panel data regressions for our sample. ***, **, *: statistics are significant to the respective thresholds of $1 \%, 5 \%$ and $10 \%$.

\begin{tabular}{|c|c|c|c|c|c|c|}
\hline & \multicolumn{2}{|c|}{ LnRemTot } & \multicolumn{2}{|c|}{ LnRemFix } & \multicolumn{2}{|c|}{ Bonus Ln } \\
\hline & Coef. & $\mathbf{Z}$ & Coef. & $\mathbf{Z}$ & Coef. & $\mathbf{Z}$ \\
\hline Constant & $14.1109 * * *$ & 46.04 & $13.5037 * * *$ & 88.96 & $14.5263 * * *$ & 22.97 \\
\hline Discrepancy & -0.8694 & -1.13 & 0.6050 & 1.31 & -0.2781 & -0.16 \\
\hline Herfindahl & $-0.0286 * * *$ & -2.73 & -0.0008 & -0.28 & -0.0384 & -0.85 \\
\hline Kalflle & -0.0904 & -0.64 & 0.0705 & 0.37 & $-0.8394 * *$ & -2.24 \\
\hline IndCA & $-0.4156 *$ & -1.82 & $-0.4912 * *$ & -2.46 & $-1.6913 * * *$ & -2.68 \\
\hline Duality & 0.0372 & 0.60 & 0.0559 & 1.46 & $0.3439 * *$ & 2.56 \\
\hline LnActif & 0.0144 & 0.41 & 0.0118 & 0.74 & -0.0659 & -0.94 \\
\hline ROE & $-0.0006 * *$ & -2.18 & $-0.0005 * * *$ & -3.83 & -0.0006 & -1.31 \\
\hline Endt & 0.0047 & 0.29 & -0.0044 & -0.29 & -0.0012 & -0.01 \\
\hline F-test & & & & & & \\
\hline
\end{tabular}

Regarding the other control variables, it appears that neither the size of the company nor its debt level significantly influence executive compensation. Also note the existence of a negative and significant effect on performance, as measured by return on equity (ROE), by the level of total and fixed compensation. This result contradicts those found in the literature (Kato et al. (2006)). Such a negative impact can be explained by the fact that firms with low profitability have more interest to pay the top executives who may be interested. So these companies would offer higher salaries to attract the best talent to drain their performance (Cheng and Firth (2006).

Table 6 shows the results of a logistic regression examining the effect of the ownership structure of French firms on the decision to award options (Attso) to managers, controlling for the effect of variables characterizing the Board, size, performance and debt (Model 4 of each of equations 1 and 2).

The results in Table 6 show that firms with concentrated ownership (Conc) have little tendency to grant stock purchase options to their executives. This strengthens the result previously found and reinforces the idea that the controlling shareholder is a substitute for compensation based on performance.

Table 6 also reports that institutional shareholders (Invins) significantly promote the use of share purchase option plans. This result is in line with the thesis of expropriation, which states that institutional investors use tunneling mechanisms for appropriating private benefits through the compensation mechanism of buying options. Such shareholders may thus be required to use their power in the firm to assign private benefits of control through the options to purchase shares. Similarly, this positive impact can be explained by the fact that institutional investors tend to have a myopic behavior by encouraging managers to increase business performance by distributing share purchase options. Possible complementarity may also exist between these two governance mechanisms.

On variables representing the board, we note the appearance of a positive and significant effect on the percentage of independent directors. This result is contradictory to that found above for variable pay level. Finally, we note that small firms are trying to give more emphasis to option plans in order to ensure alignment between the interests of the manager and those of shareholders. 
Table 6. Estimation Results Of The Regressions Of Granting Stock Options (Model 4 Equations 1 And 2 )

This table shows the regression results of a panel data model of stock options for our sample. ***, **, *: statistics are significant to the respective thresholds of $1 \%, 5 \%$ and $10 \%$.

\begin{tabular}{|c|c|c|c|c|}
\hline & Coef & $\mathbf{Z}$ & Coef & $\mathbf{Z}$ \\
\hline Constant & $2.2800 * * *$ & 4.58 & 1.7580 & 3.66 \\
\hline Concent & $-0.9679 * * *$ & -3.01 & & \\
\hline Herfindahl & & & 0.0156 & 0.37 \\
\hline Discrepancy & & & 1.1094 & 0.67 \\
\hline InvIns & $0.5835 *$ & 1.71 & & \\
\hline Kal Dirig & -0.2940 & -0.55 & & \\
\hline Kal Flle & & & 0.6469 & 1.19 \\
\hline IndCA & $1.6042 * * *$ & 3.36 & $1.7821 * * *$ & 3.69 \\
\hline Duality & -0.2527 & -1.50 & $-0.3952 * *$ & -2.24 \\
\hline LnActif & $-0.1813 * * *$ & -3.99 & $-0.1554 * * *$ & -3.47 \\
\hline ROE & -0.0001 & -0.17 & 0.0000 & 0.12 \\
\hline Endt & 0.1307 & 1.03 & 0.1312 & 1.15 \\
\hline Wald chi2 & \multicolumn{2}{|c|}{$\begin{array}{c}44.67 * * * \\
0.0000\end{array}$} & \multicolumn{2}{|c|}{$\begin{array}{c}33.01 * * * \\
0.0001\end{array}$} \\
\hline
\end{tabular}

\section{CONCLUSIONS}

The aim of this paper is to study the effect of ownership structure (concentration, discepancy) on executive compensation (compensation level and allocation of stock options to shares) while controlling for some variables characterizing the Board of Directors (composition and dual functions), performance (yield of equity), size and debt. This article is an extension of the existing literature on compensation policy. To our knowledge, no research has addressed the issue as we did. This is even more so in that the empirical investigation of this research relates to a sample of French companies listed on the SBF 120 index over the period of four years from 2007 to 2010. In the empirical part, we considered various models to study the characteristics of ownership structure, namely the concentration of ownership, and the discrepancy and type of shareholder (managers, family, institutional investor).

The main findings coming from this study do not all converg with previous work on international contexts. The results allowed us to conclude that the concentration of ownership negatively affects both the level of total executive compensation and the probability of using incentive plans based on options to purchase shares. This result suggests the existence of a substitution effect between ownership concentration and managerial compensation policy. Indeed, the majority shareholders are considered to be a guarantee of safety permitting the protection of the interests of minority shareholders.

The use of stock option incentive plans and excessive compensation in this kind of structure is very pronounced. This result thus strengthens the alignment hypothesis. Moreover, the results of our research show no evidence of the existence of a significant effect of the difference between ownership and voting on policies of managerial compensation.

The type of shareholders also seems to impact executive compensation differently. Indeed, the results show no significant effect of institutional ownership on the level of compensation. However, it turns out that such shareholders encourage the use of incentive plans based on options to purchase shares. Similarly, our results show that the share of managers positively and significantly influences the level of their total and fixed compensation. This result confirms the hypothesis that assumes rooting managers benefit from their holdings of a significant fraction of the capital to force administrators to tolerate the payment of a total high fixed compensation. Similarly, it appears that family ownership negatively affects variable executive compensation. This result confirms the hypothesis of alignment of private benefits. Indeed, family members become more involved in the management of the firm, thus affecting executive compensation by reducing their excessive withdrawals.

Moreover, it turns out that in the French context, the presence of independent directors on the board reduces the incentive to award high salaries (total, fixed and variable) and promotes the adoption of incentive-based options plans to purchase shares in order to ensure an alignment of interests of executives with those of shareholders. Similarly, the results of our investigation show that combining the functions of CEO and chairman of 
the board tends to increase the variable portion of executive compensation. In this case, the president and top director wields great power in the selection of directors and then in fixing their compensation. Regarding the other control variables, it appears that neither the size of the company nor its debt levels significantly influence the level of executive compensation. In contrast, we find that small firms tend to choose more incentive plans based on options to purchase shares. Finally, we detect the existence of a negative and significant effect of the return on equity on total and fixed compensation.

In short, the results found in this article may be an extension of the existing literature. Identifying the determinants of compensation policy may be relevant in the design of managerial compensation contracts. This is especially important in a crisis where every business must develop the best ways to survive and perform.

\section{AUTHOR INFORMATION}

Dr. Rim Ben Hassen Riahi is Assistant in finance at Higher Trade School in Tunisia (ESC Tunisia) and researcher in GEF2A Lab (Corporate governance, Applied Finance and Audit)). She has a Masters in Finance (2004) of the Higher Institute of Management (University of Tunisia) and a Masters in Finance and International Trade (2007) Higher Institute of Management (University of Tunisia). She received a Ph.D in Finance of Higher Institute of Management Tunis-Tunisia in 2014. Her main research interests focus on executive compensation, corporate governance and the quality of results.

Jihene EL OUAKDI received her Ph.D in Finance from Laval University in Quebec, Canada. She currently works as an Assistant Professor at the Higher School of Digital Economy in Tunisia. Jihene has taught at several institutions including Laval University, the Higher School of Economic and Commercial Sciences of Tunis and the Higher Institute of Business Administration of Gafsa. Dr. El Ouakdi's primary research interests cover managerial compensation, corporate governance, strategic change and innovation. During her studies she was awarded a number of academic honors and she has published several research articles on a variety of finance topics.

Abdelwahed OMRI is a Full Professor of Finance and Accounting at the High Institute of Management in Tunisia. He teaches in different programs, primarily for the Master and Doctoral programs. He is Head of GEF2A Lab (Corporate governance, applied finance and audit). His research focuses on aspects of Corporate Governance, International Financial Reporting, Applied Finance, risk and Islamic Banks. He is author or co-author of more than 40 scientific papers.

\section{REFERENCES}

Barak, R., Cohen, S., Lauterbach, B., (2011). The effect of CEO pay on firm valuation in closely held firms. International Corporate Governance. 14, 19-42.

Barkema, H.G., Gomez-Mejia, L.R. (1998). Managerial compensation and firm performance: A general research framework. Academy of Management Journal, 41, 2, 135-146.

Barontini, R., S. Bozzi. (2011). Board compensation and ownership structure: empirical evidence for Italian listed companies. Journal of Management and Governance, 15, 59-89.

Basu, S., Hwang, L. , Mitsudome, T. , Weintrop, J.(2007). Corporate governance, top executive compensation and firm performance in Japan. Pacific-Basin Finance Journal.15, 56-79.

Bebchuk L., Kraakman R., Triantis G., (1999). Stock pyramids, cross-ownership, and the dual class equity: the creation and agency costs of separating control from cash flow rights. Harvard Law and Economics Discussion Paper. 249, 295-315.

Bebchuk, L. A., Fried, J. M. (2003). Executive compensation as an agency problem. Journal of Economic Perspectives. 17, 71-92.

Ben Amoako-Adu, Vishaal. B, Brian.F.S. (2011), Executive compensation in firms with concentrated control: The impact of dual class structure and family management. Journal of Corporate Finance, 17, 1580-1594.

Ben Amoako-Adu, Vishaal. B, Brian.F.S. (2011), Executive compensation in firms with concentrated control: The impact of dual class structure and family management. Journal of Corporate Finance, 17, 1580-1594.

Bertrand.M. Schoar.A. (2006). The role of family in family firms. Journal of Economic Perspectives. 20, 73-96. 
Boubaker, S., Labégorre, F. (2006). Environnement Informationnel et Structure de Propriété et de Contrôle des Sociétés Cotées Françaises. Finance Contrôle Stratégie, 9, 5-38.

Cheng, S., M. Firth (2006). Family Ownership, Corporate Governance, and Top Executive Compensation. Managerial and Decision Economics. 27, 549-561.

Claessens, S., Djankov, S., Fan, J. P. H., Lang, L. H. P. (2002). Disentangling the incentive and entrenchment effects of large shareholders. Journal of Finance, 57, 2741-2771.

Core, J. E., Guay, W. (1999). The use of equity grants to manage optimal equity incentive levels, Journal of Accounting and Economics 28, 151-184.

Core.J.E, Larcker.D. (2002). Performance consequences of mandatory increases in executive stock ownership, Journal of Financial Economics. 64. 317-340.

Croci.E., Gonenc.H., Ozkan.N., (2012). CEO compensation, family control, and institutional investors in continental Europe. Journal of Banking \& Finance, Forthcoming.

Croci.E., Gonenc.H., Ozkan.N., (2012). CEO compensation, family control, and institutional investors in continental Europe. Journal of Banking \& Finance, Forthcoming.

Faccio M., Lang, L. H. P. (2002). The ultimate ownership of Western European corporations. Journal of Financial Economics, 65, 365-95.

Fama, E.F., Jensen, M.C. (1983). Separation of Ownership and Control Journal of Law and Economics, 26, 2, 301325.

Ginglinger E., L'Her JF. (2006). Ownership structure and open market stock repurchases in France. The European Journal of Finance, 12, 77-94.

Gomez-Mejia, L. R., Larraza, M., Makri, M. (2003). The determinants of CEO compensation in family-controlled public corporations. Academy of Management Journal. 46, 226-237.

Gomez-Mejia, L. R., Nunez-Nickel, M., Gutierrez, I. (2001). The role of family ties in agency contracts. Academy of Management Journal. 44, 81-95.

Haid, A., Yurtoglu, B. (2006). Ownership structure and executive compensation in Germany. Available at SSRN.

Haid, A., Yurtoglu, B. (2006). Ownership structure and executive compensation in Germany. Available at SSRN.

Jensen, M., Meckling,W. (1976). Theory of the firm: managerial behavior, agency costs, and ownership structure. Journal of Financial Economics, 3, 305-360.

Kaplan, S. (1994). Top executive rewards and firm performance: A comparison of Japan and the U.S. Journal of Political Economy. 102, 510-546.

Kato, Takao, Kubo, Katsuyuki, (2006). CEO compensation and firm performance in Japan: evidence from new panel data on individual CEO pay. Journal of the Japanese and International Economies. 20, 1-19.

Khan, R., Dharwadkar D., Brandes P., (2005). Institutional ownership and CEO compensation: a longitudinal examination. Journal of Business Research. 58, 1078-1088.

La Porta R., Lopez-de-Silanes F., Shleifer A. (1999), Corporate ownership around the world, Journal of Finance, 54, 471-518.

Lambert R., Larker D., Weigelt K. (1993). The structure of organizational incentives. Administrative Sciences Quarterly. 38, 438-461.

Masulis, R. W., Wang, C., Xie, F. (2009). Agency costs at dual-class companies. Journal of Finance, 64, 16971727.

Mehran, H. (1995). Executive compensation structure, ownership, and firm performance. Journal of Financial Economics 38, 163-84.

Morck R., Shleifer A., Vishny R.W. (1988). Management Ownership and Market Valuation : An Empirical Analysis. Journal of Financial Economics, 20, 293.

Mtanios R., Paquerot M. (1999). Structure de propriété et sous-performance des firmes : une étude empirique sur le marché au comptant, le règlement mensuel et le second marché. Finance Con trôle Stratégie, 4, 157-179.

Mtanios R., Paquerot M. (1999). Structure de propriété et sous-performance des firmes : une étude empirique sur le marché au comptant, le règlement mensuel et le second marché. Finance Contrôle Stratégie, 4, 157-179.

Ozkan N. (2007). CEO Compensation and Firm Performance: An Empirical Investigation of UK Panel Data. University of Bristol - Department of Finance and Accounting.

Roussel P., Trepo G. (1999). Performance des grands groupes et stratégies de rétribution des dirigeants. Cahier de recherche 220, HEC - LIRHE.

Shleifer A., Vishny R.W (1986). Large Shareholders and Corporate Control. Journal of Political Economy. 94, 461488. 
Shleifer, A., Morck, R., Vishny, R. W. (1989) Alternative mechanisms for corporate control, American Economic Review 79, 842-852.

Wirtz (2009). Do high-growth entrepreneurial firms have a specific system of governance?, Working Papers FARGO. 


\section{NOTES}

